They may be measured. They are the means by which the increasing and unstoppable demands for openness in professional work may be expressed.

The mechanism for setting up targets depends on the organisational level. An agenda is already set between patient and doctor (or practice team) - even if it consists of merely the acceptance by the doctor of the medical card of a patient, who finds out more or less casually what may be expected from the practice. The move from this implicit agenda to the highly explicit one set out by Iliffe ${ }^{16}$ may be more easily achieved if a leaflet is produced setting out the practice's aims, expectations, and routines: already this habit is widespread. Helping practices to set targets could also be a natural task for the general practice facilitators being appointed in increasing numbers. Information technology might give an immense boost to target setting as data may so much more easily be collected routinely - and by staff other than doctors. Plans and protocols that may be devised by the whole practice team (Park View Surgery, Loughborough, personal communication) need be neither numerous nor ambitiously detailed and may be re-examined at intervals to see how well they are working.

Once targets are set all know what they are trying to do and whether it has been done. Then if targets suitable to the practice are set and agreed a basis for good practice may be established that will take account of differing needs, abilities, and problems; punitive and unrealistic targets and sanctions may be avoided, and performance related pay (which is going to come whether doctors like it or not) could be settled fairly.
Patients will know what they are getting and may be able to choose a practice that looks as though it will suit them. Finally, doctors would have an answer to the reasonable question asked by government: what are you doing for the money the nation lays out?

To set targets would pull together the enormously wide ranging debate about health care. Such a measure of unanimity, even at a simple level, would enable people again to feel united and hopeful about the NHS.

General Practitioner,

SIMON BARLEY

Sheffield S10 2NQ

1 Beecham L. Health and Medicines Act. Br Med f 1988:297:1411.

Standing Committee A. Health and Medicines Bill. House of Commons Official Report (Hansard) 1988 Feb 23: cols 810-42.

1988 Feb 23: cols 810-42.
Beecham L. Chairman urged to report on negotiations. Br.Med f 1988;297:1409.

3 Beecham L. Chairman urged to report on negotiations. Br.Med f 1988;297:1409. an agenda for discussion. London: HMSO, 1986. (Cmnd 9771.)

5 General Medical Services Committee. Report to special conference of local medical committees on 13 November, 1986. London: British Medical Association, 1986.

6 Medical Practitioners Union. Primary care: iur response to the government's white paper. London: MPU, 1988.

7 Consumer's Association. The NHS report. Which? 1988 Oct: 476-7.

8 Marks L. Promoting better health? An analysis of the givernment's programme for primary health care. London: King's Fund Institute, 1988. (Briefing Paper 7.)

9 World Health Organisation (Regional Office for Europe). Targets for Health for All: targets in support of European strategy for HFA. Copenhagen: WHO, 1985.

10 House of Commons Social Services Committee. First report from the social services committee 1987-8: resourcing the NHS: short-term issues. Vol I. London: HMSO, 1988.
rent

1 National Audit Office. Management of the family practitioner services. London: HMSO, 1988:7.

11 National Audit Office. Management of the family practitioner ser

12 Hart JT. A new kind of doctor. London: Merlin, 1988:237-41.
13 Gray DJP, ed. The medical annual. Bristol: Wright, 1985:282-300.

13 Gray DJP, ed. The medical annual. Bristol: Wright, $1985: 282-300$.
14 Fullard E, Fowler G, Gray M. Promoting prevention in primary care: controlled trial of lowFullard E, Fowler G, Gray M. Promoting prevention in pring
technology, low-cost approach. Br.Med f 1987;294: 1080-2.

15 Standing Committee A. Health and Medicines Bill. House of Commons Official Report (Hansard) 1988 Feb 23: cols 846-79.

16 Iliffe S. Strong medicine. London: Lawrence and W'ishart, 1988:141-5.

\title{
Golden Anniversary of the "British Heart Journal"
}

\section{A Canadian who has known all the editors reflects}

A new journal was born in 1939, the accoucheurs being the members of the Cardiac Society of Great Britain and Ireland. The foreword in the first issue of the British Heart Fournal was written by Sir Thomas Lewis, who called for "quality." The same issue contained "Notes on the Cardiac Club," whose conception had been inspired many years before by James Mackenzie in Burnley. Sir James was elected the only honorary member. In 1937 the club grew into the Cardiac Society, and it was fitting that the first volume of the journal should contain a paper on the pathology of Sir James's heart.

The journal Heart had been published from 1909 to 1933 under the strong, possibly dictatorial, editorship of Sir Thomas Lewis. This journal was transformed into a new publication, Clinical Science, incorporating Heart. Lewis's vision of the changed journal was of an outlet for reports in his new science of clinical investigation. The organisers of the new cardiac society, primarily consultants on diseases of the heart, were convinced that there was a place for a journal focusing on the diseases of the heart. Concomitantly, they would create a medium for publishing the proceedings of the regular meetings of the Cardiac Society.

In its 50 years the British Heart Fournal has changed little in format or in the nature of its content. It has been predominantly clinical in orientation, and the editors have earned accolades for clarity and crispness in style. Editorials became a regular feature in the journal about 1967, and often they were spirited and provocative.

Landmark papers or citation classics are not readily identified in the British Heart Fournal, but many of the articles have become standard references. I recognise that nothing traditionally becomes a classic until over 20 years have passed. My idiosyncratic nominations of three papers from the first three decades are, however, Thompson on potassium and the heart (1939); Parkinson and others on the electrocardiogram of Stokes Adams (1944); Bramwell and Morgan Jones on collateral circulation of coarctation (1941); McMichael and Sharpey-Schafer on measuring cardiac output by the direct Fick method (1944); Emslie-Smith on intracardiac electrograms (1955); Teare on asymmetric hypertrophy (1958); Wood on polyuria in tachycardia (1963); Goodwin and others on hypertrophic obstructive cardiomyopathy (1964); and Barlow and others on clicks and late systolic murmurs (1968).

The historical essays in the British Heart fournal have been an attractive feature to me, particularly those from the pen of Evan Bedford, a joint editor of the journal at its inception. Named lectures have often appeared in the journal, and I have found the ones named for Sir Thomas Lewis particularly instructive.

For several decades there have been the predictions that the traditional journals such as the British Heart fournal would be replaced by the new technological wizardry in storing, retrieving, and displaying data. Death knells have been premature so far; old ways do not die easily. Possibly some one will have to wait until the diamond jubilee of 2014 to write a final eulogy.

St Paul,

HOWARD B BURCHELL

Minnesota 55105

United States 